\title{
ECOLOGICAL STUDIES ON THE MANGO SCALE INSECT, AULACASPIS TUBERCULARIS (NEWSTEAD) (HOMOPTERA: DIASPIDIDAE) INFESTING MANGO TREES UNDER FIELD CONDITIONS AT QUALUBIA GOVERNORATE
}

\author{
FAYZA A. KWAIZ
}

Plant Protection Res. Inst., ARC, Dokki, Giza

(Manuscript received 27 May 2008)

\begin{abstract}
The research work was conducted during two successive years 2005 and 2006 on the seasonal abundance and some ecological aspectsof the mango scale insect, Aulacaspis tubercularis infesting mango trees at Qualubia Governorate .

The obtained results denoted that this insect had three peaks which occurred during March, June and November through each of the two studied years while the lowest population was registrated in mid. July Also, data clearly showed that $A$. tubercularis had four overlapping annual generations during the two studied years. Statistical analysis showed that the climate factors affected the activity of $A$. tubercularis. Results proved that there were positive correlation between temperature (Min. \& Mix.) and all annual generations through the two studied years except the third one. The data proved a negative correlation between R.H \% and all insect generations except the second one in the first year.

It is advisable to apply pesticides from mid July till the end of August as summer spraying which was more suitable for, controlling $A$. tubercularis infesting mango trees .
\end{abstract}

\section{INTRODUCTION}

Mango, Mangifera indica (L.) is consider as one of the most popular fruits in Egypt. The mango is the third major crop after citrus and grape. There are several species of the scale insects are attacking mango trees .

Among these pests, the mango scale insect, Aulacaspis tubercularis (Newstead) (Homoptera: Coccoidea : Diaspididae) which causing severe damages to the leaves represented in yellowish leaves and defoliated vegetative growth .

Although the mango scale insect does not cause internal fruit damage, its cosmetic effect on the fruit skin results in a significant decrease in the ratio of the exportable fruit. Also, it is believed that most species of armored scale insects release phytotoxic substances (Mc Clure 1990). The present investigation aimed to study some ecological aspects of the mango scale insect, Aulacaspis tubercularis on mango trees at Qualubia governorate during two successive years (2005-2006) to achieve to the proper time for successful control under field conditions. 


\section{MATERIALS AND METHODS}

Ecological studies on the mango scale insect, Aulacaspis tubercularis (Newstead) was carried out for two successive years from January 2005 till the end of December 2006 at Qualubia Governorate .

Mango orchard was about 3 feddans with aged about 40 years with about 8-12 meter high. No chemical control was carried out before and throughout the period of the investigation and all trees received the same agricultural practices.

Successive fortnightly samples of 30 leaves from three mango trees replicated three times (nine trees). Samples were taken and kept in a paper bags in order to transfer them to the laboratory for examination. Samples were examined carefully by the aid of stereomicroscope binocular. All the living immature stages, adult females and gravid females of $A$. tubercularis were sorted and counted separately .

- The rate of increasing in the population was calculated by (Bodenheimer 1951).

The formula =

Average count during the month

Average count during the preceding one

- Number of annual generations for $A$. tubercularis was estimated from changes in the mean half monthly nymphal stages counts throughout two successive years (2005-2006). Data were worked out according to Jacob's formula (1977) and graphically illustrated on semiganssion paper for estimating number and duration of generations .

- Simple correlation ( $r$ ) was calculated to assess the effect of main weather factors (daily Min.temp., daily. Max. temp., and daily relative humidity) on A. tubercularis generations .

\section{RESULTS AND DISCUSSION}

\section{1- Seasonal fluctuations of the mango scale insect, Aulacapis tubercularis population}

Data represented in tables $(1,2)$ which graphically illustrated in Figs (1) revealed that $A$. tubercularis had 3 peaks of abundance through each of the two studied years .

In the first year of study, (2005) the population of insect showed 3 peaks which occurred during mid March (77.90 individuals/leaf), early June (105.2 individuals /leaf) and early November (76.20 individuals/leaf). 
In the second studied year investigation (2006) the three peaks were recorded in mid March (60.4 individuals /leaf), mid June (157.20 individuals /leaf) and early November (85.30 individuals /leaf) .

Data in tables $(1,2)$ indicated that the highest peak of $A$. tubercularis population was recorded during June through the two years of investigation, in which the weather factors recorded $33.45,32.46{ }^{\circ} \mathrm{C}$ for D. Max. Temp., $19.32,19.30^{\circ} \mathrm{C}$ for N. Mini Temp., and $63.94 \%, 53.36 \%$ for D.M.R.H .

On the other hand, the lowest population were recorded in January, mid July and mid December with mean total population (25.6, 20.50 individuals /leaf), (10.4, 28.60 individuals /leaf) and $(25.90,22.40$ individuals /leaf) through the two years of investigation, respectively.

The lowest peak of $A$. tubercularis was recorded in mid July this may be due to the high temperature prevailing at that time.

Table 1. 
74 ECOLOGICAL STUDIES ON THE MANGO SCALE INSECT, AULACASPIS TUBERCULARIS (NEWSTEAD) ( HOMOPTERA: DIASPIDIDAE) INFESTING MANGO TREES

UNDER FIELD CONDITIONS AT QUALUBIA GOVERNORATE 
Table 2. 
(NEWSTEAD) ( HOMOPTERA: DIASPIDIDAE) INFESTING MANGO TREES

UNDER FIELD CONDITIONS AT QUALUBIA GOVERNORATE

Fig .1 
Fig. 2 


\section{2- Seasonal fluctuations of the pre-adult stages}

Data in tables $(1,2)$ and Fig $(2)$ clearly showed that $A$. tubercularis pre-adults during each of 2005-2006 recorded 3 peaks, (in mid March, $1^{\text {st }}$ July and $1^{\text {st }}$ November) the highest peak was in $1^{\text {st }}$ of July (21.00 individuals /leaf) in the first year and 26.40 individuals/leaf in the second one.

On the other hand, the lowest pre-adult population recorded in first of February with (3.80 individuals /leaf) in the first year (2005) and 4.10 individuals /leaf) during the second one (2006).

\section{3- Seasonal fluctuations of the adults females}

Data in tables $(1,2)$ and fig $(2)$ cleared that the population of the adult females through the two studied years had the same trend .

Females population had three peaks recoded in $15^{\text {th }}$ March, $1^{\text {st }}$ July and $1^{\text {st }}$ November whereas, they showed the lowest population in mid January with 1.80 insect/leaf in the first year and 2.90 individuals/leaf in the second one.

\section{4- Seasonal fluctuation of the gravid females}

Data in the same tables clearly showed that $A$. tubercularis gravid females had three peaks through each of the two years. The highest peaks were observed in $15^{\text {th }}$ March and $1^{\text {st }}$ June with 61.70 and 72.80 individuals /leaf), respectively in the first year .

However, the highest peaks were recorded in $15^{\text {th }}$ March and $15^{\text {th }}$ June with 36.20 and 92.80 individuals /leaf), respectively, in the $2^{\text {nd }}$ year. The smallest peak was recorded in $15^{\text {th }}$ October with 29.80 individuals/leaf in the first year and with 30.30 individuals /leaf in the second one.

On the other hands, the lowest gravid females was achieved in July through the two years of study .

\section{5- Number and duration of Aulaeaspis tubercularis generations on mango trees}

Data in table $(3,4)$ and Fig $(3,4)$ showed that four annual generations were recorded through each of the two studied years (2005 \& 2006). They happened as follows :-

- First generation. extended for 3 months started from $1^{\text {st }}$ of January till the end of March through the two years of study . 
- Second generation. Also, elapsed 3 months, beginning from $1^{\text {st }}$ of April till the end of June in the first year 2005, but it started from $1^{\text {st }}$ of April till mid of July (3.5 months) in the second year, 2006 .

- Third generation started from $1^{\text {st }}$ of July till mid of October (3.5 months) in the first year but it started from mid of July till mid of October ( 3 months) in the second one .

- Fourth generation was the shortest generation where it started from mid of October till end of December extended for 2.5 month through two years of experiments .

The results disagreed with those obtained by Radwan (2003) who reported that A. tubercularis had 3 generations on mango trees at Beni-Sweif governorate.

This prolonged durations caused further overlapping between generations. This is in agreement with Labuschagne et al.(1995) and Radwan (2003).

Table 3. Simple correlation between three tested climatic factors and the annual generations of Aulacaspis tubercularis on Mango trees in Qualubia Governorate during (2005) .

\begin{tabular}{|l|c|c|c|c|}
\hline \multirow{2}{*}{ Generation } & \multirow{2}{*}{ durations } & \multicolumn{3}{c|}{ "r" } \\
\cline { 3 - 5 } & & D.Mx. T & N.Min.T & R.H.\% \\
\hline 1- Fist generation (1 ${ }^{\text {st }}$ of Jan-last of Mar.) & 3months & $0.868 *$ & 0.798 & $-0.862 *$ \\
\hline 2- Second generation (1 ${ }^{\text {st }}$ of April-last of June) & 3 months & 0.457 & 0.533 & 0.672 \\
\hline 3- Third generation (1 $1^{\text {st }}$ of July-mid of Oct.) & $31 / 2$ months & $-0.906 * *$ & $-0.845^{*}$ & -0.741 \\
\hline 4- Fourth generation (mid of Oct.-last of Dec.) & $21 / 2$ months & 0.837 & $0.904 *$ & -0.358 \\
\hline
\end{tabular}

$r$ : Correlation coefficient value.

* Correlation is significant at the 0.05 Level .

Table 4. Simple correlation between three tested climatic factors and the annual generation of Aulacaspis tubercularis on Mango trees in Qualubia Governorate during (2006) .

\begin{tabular}{|l|c|c|c|c|}
\hline \multirow{2}{*}{ Generation } & \multirow{2}{*}{ Durations } & \multicolumn{3}{c|}{ "r" } \\
\cline { 3 - 5 } & & D.Mx. T & N.Min.T & R.H.\% \\
\hline 1- Fist generation (1 ${ }^{\text {st }}$ of Jan-last of Mar.). & 3 months & 0.513 & 0.085 & -0.718 \\
\hline 2- Second generation (1 ${ }^{\text {st }}$ of April-mid of July) & $31 \frac{1}{2}$ months & $0.899 * *$ & $0.896 * *$ & -0.0242 \\
\hline 3- Third generation (mid of July-mid of Oct.) & 3 months & -0.641 & -0.644 & -0.058 \\
\hline 4- Fourth generation (mid of Oct.-last of Dec.) & $21 \frac{1}{2}$ months & 0.602 & 0.688 & -0.770 \\
\hline
\end{tabular}

r: Correlation coefficient value.

* Correlation is significant at the 0.05 Level .

6- The relation between climatic factors and $A$. tubercalaris generations on the mango trees :-

(A) Effect of the maximum temperature on the different generations

1- The first generation : There was a positive correlation between maximum temperature and this generation during the two studied years, the correlation was significant in the first year but it was insignificant in the second one (tables $3 \& 4$ ). 
(NEWSTEAD) ( HOMOPTERA: DIASPIDIDAE) INFESTING MANGO TREES

UNDER FIELD CONDITIONS AT QUALUBIA GOVERNORATE

Fig. 3. 
2- The second generation : There was a positive correlation between maximum temperature and the second generation in the two studied years. The correlation was insignificant in the first year but it was highly significant during the second one.

3- The third generation : The correlation between maximum temperature and the third generation was negative during the two years of investigation but its effect was highly significant during the first year .

4- The fourth generation : The effect Max. temperature was positive and insignificant through the two years of study .

(B) Effect of the minimum temperature on the different generations :-

1- The first generation : There was a positive and insignificant correlation between Min. temperature and the first generation during the two years of study Tables (3\&4).

2- The second generation : The correlation between Min. temperature and the second generation was positive during the two years. The correlation was insignificant in the first year but it was highly significant in the second one Tables (3\&4).

3- The third generation : The effect of Min. temperature through the two years of study was negative and its effect was significant during the first year only. (Tables $3 \& 4)$.

4- The fourth generation : There positive correlation between Min. temperature and this generation during the two studied years the correlation was significant in the first year but it was insignificant in the second one Tables (3\&4).

\section{(C) Effect of R.H\%}

Statistical analysis in tables (3\&4) cleary showed that the correlation between the four annual generations and the relative humidity was negative except the $2^{\text {nd }}$ generation during $1^{\text {st }}$ year. The effect of $\mathrm{R} . \mathrm{H} \%$ on annual generation of $A$. tubercularis on mango was insignificant except the $1^{\text {st }}$ generation in the first year .

The climatic factors, particularly temperature, and humidity have the most effect on armored scale insect and play a major role in its population dynamics .

Labuschangne et al., (1995), Hassan (1998), Kwaiz (1999 , 2003) and Radwan (2003), found interrelation between population peaks of the mango scale insect and the highest mean temperature .

It is advisable to apply pesticides for controlling the mango scale insect, $A$. tubercularis that infesting Mango trees from mid July till late August as summer spraying which was more suitable 


\section{REFERENCES}

1. Bodenheimer, F. S. 1951. Citrus Entomology in The Middle East, Textbook, 301320 and 364-381.

2. Hassan, N. A. 1998. Ecological studies on Insulaspis pallidula on mango trees. J. Agric. Sci. Mansoura Univ., 23 (8) 3979-3986 .

3. Jacob, N. 1977. Un mode mathematic pentra stabilirea limitelor economice de toleranta a atacului moliilor Fructelor in lupte integrate. Analele I.C.P.P. 15 .

4. Kwaiz, F. A. M. 1999. Ecological and toxicological studies on the mango soft scale Kilifia acuminate (Signoret) with special reference to insecticide residues in Mango fruits. Ph. D. Thesis Fac. Of Agric. Cairo Univ., 171 pp .

5. Kwaiz, F. A. M. 2003. Ecological studies on Insulaspis pallidula on Mango trees and its associated parasites at Qena Governorate AL-Azhar J. Agric. Res., pp. 79 - 92 .

6. Labuschangne, T. I., H. V. Hamburg, I. J. Froneman, K. R. S. Ascher and Y. Ben. Dov. 1995. Population dynamics of the mango scale, Aulacaspis tubercularis (Newstead) (Coccoidea : Diaspididae) in South Africa. Israel J. Entomol., 29 : 207217 .

7. Mc Clure, M. S. C. 1990. Impact on host plant, Armored scale insets (Hemiptera : Sternorrhyncha : Coccoidea) present in Soroa orchids garden, Pinar del Rio, Cuba. Fitosanidad, 8 (3) : 25 -29 .

8. Radwan., S. G. A. 2003. Toxicological studies on some scale insects infesting Mango and Guava trees (Ph. D. Thesis, Fac. of Agric., Cairo Univ.), 221 pp. 


\section{دراسات بيئية لحشرة المانجو القشرية التى تصبب أشجار المانجو تحت الظروف الحقلية فى محافظة القليوبية}

\section{فايزة أحمد كويز}

$$
\text { معهد بحوث وقاية النباتات - مركز البحوث الزراعية - الدقى - الجيزة . }
$$

أجريت هذه الدراسات البيئية على حشرة المانجو القشرية التي تصيب أشجار المانجو بمحافظة

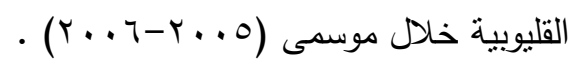

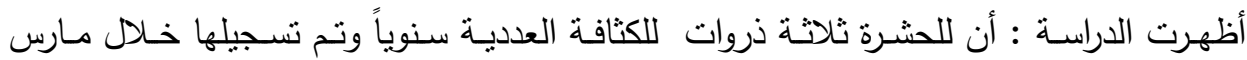
ويونية ونوفمبر وكان أقل تعداد للحشرة خـلال شهر يولية وكان لحشرة المـانجو القشرية أربعة أجيال

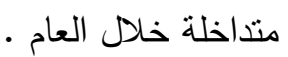
وقد أظهر التحليل الإحصائى تأثير العوامل الجوية على نشاط الحشرة حيث وجدت علاقة موجبة

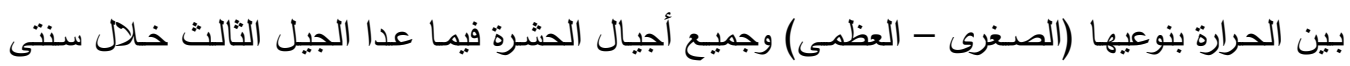
الدراسة. وكانت العلاقة سالبة بين عامل الرطوبة وأجيال الحشرة فيما عدا الجيل الثانى فى السنة الأولى لئى ومن خلال هذه الدراسة يمكن التوصل إلى أن أنسب ميعاد لمكافحة حشرة المانجو القشرية هو التوقيت الصيفى الذى يبدأ من منتصف يوليو حتى آخر أغسطس. 